\title{
PENERAPAN MODEL TALKING STICK UNTUK MENINGKATKAN MOTIVASI DAN HASIL BELAJAR SISWA PADA MATA PELAJARAN IPA SMP
}

\author{
Suhada \\ SMP Negeri 11 Kota Bima
}

INFO ARTIKEL

Diterima:28-12-2019

Disetujui:7-2-2020

\begin{abstract}
Abstrak: Salah satu tugas guru adalah menyelenggarakan pembelajaran yang inovatif dengan cara melakukan variasi pada model pembelajaran di kelasnya. Salah satu model pembelajaran yang dapat digunakan adalah talking stick. Sebab menurut observasi awal ditemukan bahwa siswa tidak tertarik pada mata pelajaran IPA, kurang motivasi dan nilai hasil belajar yang rendah. Penelitian Tindakan Kelas ini bertujuan untuk mengetahui: 1) Apakah penerapan model talking stick dapat meningkatkan motivasi belajar siswa dalam mata pelajaran IPA SMP?; dan 2) Apakah penerapan model talking stick dapat meningkatkan hasil belajar siswa dalam mata pelajaran IPA SMP?. Penelitian ini dilaksanakan di kelas VIII SMP Negeri 11 Kota Bima tahun pelajaran 2017/2018 pada bulan Februari sampai dengan April 2018. Penelitian dilakukan dalam 2 siklus. Analisis data menggunakan analisis data kualitatif dan kuantitatif. Hasil penelitian: 1) penerapan model talking stick dapat meningkatkan motivasi belajar siswa dalam mata pelajaran IPA SMP, karena siswa yang memiliki motivasi tinggi dan sangat tinggi pada siklus II sebanyak 21 orang atau 91\%. 2) penerapan model talking stick dapat meningkatkan hasil belajar siswa dalam mata pelajaran IPA SMP, karena siswa yang berhasil memenuhi nilai minimal KKM 70 pada siklus II sebanyak 21 orang atau $91 \%$.
\end{abstract}

Kata Kunci:

Talking Stick, Motivasi, Hasil Belajar, IPA

\begin{abstract}
One of the teacher's tasks is to organize innovative learning by varying the learning model in the class. One learning model that can be used is a talking stick. Because according to preliminary observations it was found that students were not interested in natural science subjects, lacked motivation and low learning outcomes. This Classroom Action Research aims to find out: 1) Does the application of the talking stick model increase student motivation in junior high school science subjects ?; and 2) Can the application of the talking stick model improve student learning outcomes in junior secondary science subjects? This research was conducted in class VIII of SMP Negeri 11 Kota Bima in the 2017/2018 academic year from February to April 2018. The research was conducted in 2 cycles. Data analysis uses qualitative and quantitative data analysis. The results of the study: 1) the application of the talking stick model can increase student motivation in junior high school science subjects, because students who have high motivation and are very high in cycle II are 21 people or $91 \%$. 2) the application of the talking stick model can improve student learning outcomes in junior high school science subjects, because students who successfully meet the minimum value of KKM 70 in cycle II are 21 people or $91 \%$.
\end{abstract}


Alamat Korespondensi:

Suhada

SMP Negeri 11 Kota Bima

Jln. Datuk Dibanta Kel. Jatibaru Kec. Asakota Kota Bima

Email : suhada78bima@gmail.com

Sebagai profesi yang bertugas mencerdaskan kehidupan bangsa, peran serta guru harus lebih ditingkatkan terutama dalam menyiapkan diri menghadapi tantangan-tantangan di dunia pendidikan. Tantangan di dunia pendidikan sangat beragam jumlah dan jenisnya, diantaranya adalah beragamnya karakter dan situasi peseta didik sehigga seorang guru perlu memvariasikan cara, model, metode, pendekatan, maupun teknik pembelajaran yang tepat untuk diaplikasikannya dalam kelas yang beragam pula.

Tujuan dari penggunaan variasi model pembelajaran ini diharapkan adanya peningkatan hasil belajar yang diperoleh siswa sehingga tujuan dari pembelajaran tersebut dapat tercapai. Selain itu dengan melakukan variasi model pembelajaran diharapkan proses belajar menjadi lebih menyenangkan dan dapat membangkitkan motivasi dalam diri siswa, Hasil belajar merupakan capaian seseorang siswa dalam belajar yang mana selain ditentukan oleh motivasi siswa juga dipengaruhi oleh metode belajar yang diterapkan oleh gurunya.

Namun keadaan yang idealis seperti itu ternyata tidak selamanya terjadi secara nyata di lapangan. Pengamatan penulis di lapangan menunjukkan bahwa masalah yang terjadi dalam proses belajar-mengajar terutama yang berhubungan dengan motivasi dan hasil belajar di SMP Negeri 11 Kota Bima masih belum mencapai kondisi ideal seperti yang diharapkan. Berdasarkan observasi awal yang dilakukan penulis pada kelas VIII-A SMP Negeri 11 Kota Bima pada tahun pelajaran 20172018 dengan jumlah siswa sebanyak 23 orang, disimpulkan bahwa masih terdapat 15 siswa atau sekitar 65\% siswa yang masih pasif dalam pembelajaran serta kurang tertarik dalam mengikuti mata pelajaran IPA. Akibat tidak ada ketertarikan ini dapat membuat siswa malas untuk belajar sehingga membuat nilai hasil belajar yang tercermin dalam hasil ulangan juga rendah. Berdasarkan hasil diskusi penulis dengan beberapa orang guru senior dan kepala sekolah, hal tersebut terjadi salah satunya diakibatkan oleh guru IPA yang menggunakan metode pembelajaran konvensional seperti ceramah diselingi tanya jawab, pemberian tugas dan diskusi.

Pembelajaran satu arah dengan metode ceramah yang dikembangkan guru selain membosankan juga kurang efektif dalam mencapai tujuan pembelajaran. Akibat dari penerapan metode ceramah yang diselingi tanya jawab dan pemberian tugas ini membuat siswa memiliki sikap negatif terhadap pembelajaran, malas bertanya dan menjawab pertanyaan, kurang serius dalam mengikuti pelajaran, kurang motivasi dan termotivasi dalam belajar, serta kurang menghargai dan bekerjasama sesama siswa. Guru juga jarang sekali memberikan motivasi pada siswa dalam mengajar.

Permasalahan sebagaimana tersebut di atas harus segera diatasi atau diteliti sehingga akan meningkatkan motivasi dalam pembelajaran IPA yang akhirnya akan meningkatkan hasil pembelajaran. Namun, jika tidak segera diatasi dapat memperoleh kerugian antara lain rendahnya kompetensi yang akan dicapai siswa (pengetahuan, sikap, keterampilan), hasil belajar, mutu pembelajaran dan mutu pendidikan juga ikut rendah. Oleh karena itu, guru perlu memvariasikan model belajar yang digunakan dengan tujuan meningkatkan motivasi belajar dan hasil belajar siswa.

Salah satu model yang telah banyak digunakan oleh guru dan peneliti pendidikan adalah model pembelajaran talking stick yang merupakan kegiatan belajar berbasis permainan berkelompok. Hal ini sangat bagus untuk diaplikasikan 
KARANGAN: Jurnal Kependidikan, Pembelajaran, dan Pengembangan, Vol 02, No 01, Bln Feb, Tahun 2020, Hal 7 - 14

dalam pembelajaran, karena dengan adanya permainan, siswa merasa senang dan terhindar dari rasa jenuh saat mempelajari suatu materi yang disajikan oleh gurunya. Selain itu, belajar sambil bermain akan memberikan kesempatan kepada siswa untuk lebih aktif dibandingkan model belajar yang sekedar mendengarkan penjelasan dari guru. Suwatra, dkk. (2007) menganggap bahwa model pembelajaran kooperatif memiliki tujuan untuk membantu siswa bekerja dalam diskusi kelompok, siswa mempunyai kesempatan yang sama, serta memastikan semua anggota telah belajar. Sejalan dengan itu, Kurniasih dan Berlin (2015) menganggap bahwa pembelajaran talking stick dapat menguji kesiapan siswa dalam hal penguasaan materi, melatih pemahaman materi secara cepat, siswa lebih giat belajar dan termotivasi untuk belajar karena siswa tidak pernah tahu tongkat akan sampai pada gilirannya.

Adapun sintaks pembelajaran talking stick menurut Hamzah (2014) adalah: 1) guru menyiapkan sebuah tongkat, 2) guru menyampaikan materi pokok yang akan dipelajari, kemudian memberikan kesempatan kepada peserta didik untuk membaca dan mempelajari materi pada pegangan/paketnya, 3) setelah selesai membaca buku dan mempelajarinya, guru mempersilahkan peserta didik untuk menutup bukunya, 4) guru mengambil tongkat dan memberikan kepada siswa, setelah itu guru memberikan pertanyaan dan siswa yang memegang tongkat tepat saaat musik berhenti harus menjawabnya, demikian seterusnya sampai sebagian besar peserta didik mendapat bagian untuk menjawab setiap pertanyaan dari guru, 5) guru memberikan kesimpulan, 6) evaluasi, dan 7) penutup.

Hasil penelitan terdahulu yang relevan diantaranya penelitian oleh Andayani (2016) "Pengaruh Model Pembelajaran Kooperatif Tipe Think Pair Share dan Talking Stick terhadap Motivasi dan Hasil Belajar Kognitif IPA Biologi Siswa Kelas VII SMP" menunjukkan bahwa penelitian kualitatif yang dilaksanakan di 3 SMPN dan 1 MTs di Kota Malang menggunakan pembelajaran kooperatif disimpulkan bahwa rata-rata setiap metode dapat meningkatkan motivasi belajar serta berpengaruh signifikan terhadap peningkatan nilai kognitif siswa.

Penelitian oleh Putri dkk (2017) berjudul "Penerapan Model Pembelajaran Talking Stick disertai Metode Demonstrasi Berbantuan Media Kokami Mata Pelajaran IPA di SMP" menghasilkan kesimpulan bahwa melalui penelitian perbandingan terdapat perbedaan hasil belajar antara pembelajaran yang menggunakan pembelajaran talking stick berbantuan media kokami dengan pembelajaran konvensional. Selain itu diperoleh rata-rata nilai indikator motivasi sebesar 76,7\% dengan kriteria termotivasi setelah siswa memperoleh pembelajaran menggunakan model talking stick berbantuan media kokami.

Berdasarkan uraian di atas maka penulis memutuskan untuk menggunakan model pembelajaran talking stick untuk meningkatkan motivasi dan hasil belajar IPA. Rumusan masalah penelitian ini adalah: 1) Apakah penerapan model talking stick dapat meningkatkan motivasi belajar siswa dalam mata pelajaran IPA SMP?; dan 2) Apakah penerapan model talking stick dapat meningkatkan hasil belajar siswa dalammata pelajaran IPA SMP?.

\section{METODE}

Penelitian ini merupakan Penelitian Tindakan Kelas (classroom action research) yang dilaksanakan dengan mengikuti prosedur penelitian berdasarkan pada prinsip Kemmis dan Taggart (1988) yang mencakup kegiatan perencanaan (planning), tindakan (action), observasi (observation), refleksi (reflection) atau evaluasi yang kemudian diulang kembali dalam beberapa siklus. Peneliti secara langsung hadir dalam proses pembelajaran serta menjadi fasilitator dan 
pembimbing kegiatan pembelajaran siswa. Sedangkan salah satu teman sejawat bertugas sebagai observer.

Penelitian dilaksanakan di kelas VIII-A SMP Negeri 11 Kota Bima dengan jumlah siswa sebanyak 23 orang. Penelitian ini berlangsung selama 3 bulan yaitu mulai Februari sampai dengan April 2018.

Teknik pengumpulan data yang digunakan dalam penelitian ini terdiri dari teknik: a) tes hasil belajar; b) observasi; c) dokumentasi; dan d) wawancara. Teknik analisis data menurut Miles \& Huberman dalam Aqib (2006) adalah analisis data kualitatif yang terdiri dari reduksi data, penyajian data, dan penarikan kesimpulan. Selain itu juga digunakan analisis data kuantitatif untuk menganalisis hasil belajar siswa.

Indikator keberhasilan motivasi belajar apabila apabila terdapat minimal $85 \%$ siswa telah memiliki motivasi belajar tinggi dan atau sangat tinggi. Adapun penentuan tinggi rendahnya motivasi belajar siswa menggunakan tabel 1 di bawah ini.

Tabel 1 : Kategori Motivasi Belajar Siswa

\begin{tabular}{ccc}
\hline No & Rata-rata Skor & Kategori \\
\hline 1. & $\geq 4.00$ & Sangat tinggi \\
\hline 2. & $3.00-3.99$ & Tinggi \\
\hline 3. & $2.00-2.99$ & Sedang \\
\hline 4. & $1.00-1.99$ & Rendah \\
\hline 5. & $\leq 0.99$ & Sangat rendah \\
\hline
\end{tabular}

Sedangkan indikator keberhasilan hasil belajar yang diharapkan dalam penelitian ini adalah siswa dapat mencapai nilai minimal KKM sebesar 70 . Sedangkan secara klasikal dikatakan tuntas belajar jika lebih dari $85 \%$ siswa mendapat nilai minimal KKM 70. Rumus yang digunakan untuk ketuntasan klasikal adalah:

$$
\text { Ketuntasan Klasikal }=\frac{\text { Jumlah peserta didik Tuntas }}{\text { Jumlah seluiruh peserta didik }} \times 100 \%
$$

\section{HASIL}

\section{Siklus 1}

Pelaksanaan tindakan siklus I dilaksanakan sebanyak 2 kali pertemuan yaitu pada hari Rabu, 07 Februari 2018 dan Sabtu, 10 Maret 2018. Observasi dilakukan menggunakan lembar observasi dan catatan lapangan. Hasil angket motivasi belajar yang dibagikan kepada siswa usai pelaksanaan siklus I disajikan pada tabel 2 berikut ini.

Tabel 2 : Motivasi Belajar Siswa Siklus I

\begin{tabular}{cccc}
\hline $\begin{array}{c}\text { N } \\
\text { o. }\end{array}$ & Kategori Motivasi & Jumlah Siswa & Persentase \\
\hline 1. & Sangat Tinggi & 4 orang & $17 \%$ \\
\hline 2. & Tinggi & 14 orang & $61 \%$ \\
\hline 3. & Sedang & 3 orang & $13 \%$ \\
\hline 4. & Rendah & 2 orang & $9 \%$ \\
\hline & Jumlah & 23 orang & $100 \%$ \\
\hline
\end{tabular}

Berdasarkan table 2 di atas dapat diketahui bahwa siswa yang memiliki motivasi tinggi dan sangat tinggi adalah sebanyak 18 orang atau sebanyak $78 \%$. Sedangkan sisanya sebanyak 5 orang atau sebesar $21 \%$ masih memiliki motivasi sedang dan rendah. 
KARANGAN: Jurnal Kependidikan, Pembelajaran, dan Pengembangan, Vol 02, No 01, Bln Feb, Tahun 2020, Hal 7 - 14

Untuk penilaian hasil belajar siswa pada Siklus I yang dilakukan pada akhir pertemuan ke-2 diperoleh nilai sebagaimana tabel 3 berikut.

Tabel 3 : Hasil Belajar Siswa pada Siklus I

\begin{tabular}{rcccc}
\hline No. & Jumlah Siswa & Nilai & Persentase & Keterangan \\
\hline 1. & 17 orang & $\geq 70$ & $74 \%$ & Tuntas \\
\hline 2. & 6 orang & $<70$ & $26 \%$ & Tidak Tuntas \\
\hline
\end{tabular}

Berdasarkan tabel 3 di atas diketahui bahwa dari 23 siswa, terdapat 17 orang (74\%) yang tuntas (mampu mencapai KKM 70), sedangkan sisanya sebanyak 6 orang (26\%) belum tuntas. Ketuntasan klasikal baru mencapai $74 \%$.

Dengan demikian berdasarkan hasil pada siklus I ini, nilai motivasi dan hasil belajar siswa masih belum memenuhi indikator keberhasilan tindakan yang telah ditetapkan sehingga penelitian dilanjutkan ke siklus II.

\section{Siklus II}

Siklus II pertemuan ke-1 dilaksanakan pada hari Rabu, tanggal 14 Februari 2018 dan pertemuan ke-2 dilaksanakan hari Sabtu, 17 Februari 2018. Observasi dilakukan menggunakan lembar observasi dan catatan lapangan. Berdasarkan hasil angket motivasi belajar yang dibagikan kepada siswa usai pelaksanaan siklus II diketahui hasil sebagaimana dalam tabel 4 berikut ini.

Tabel 4 : Motivasi Belajar Siswa Siklus II

\begin{tabular}{cccc}
\hline $\begin{array}{c}\text { N } \\
\text { o. }\end{array}$ & Kategori Motivasi & Jumlah siswa & Persentase \\
\hline 1. & Sangat Tinggi & 12 orang & $52 \%$ \\
\hline 2. & Tinggi & 9 orang & $39 \%$ \\
\hline 3. & Sedang & 2 orang & $9 \%$ \\
\hline \multicolumn{2}{r}{ Jumlah } & 23 orang & $100 \%$ \\
\hline
\end{tabular}

Berdasarkan tabel 4 di atas, dapat diketahui bahwa terdapat 21 orang atau sebesar $91 \%$ yang memiliki motivasi sangat tinggi dan tinggi. Sedangkan sisanya hanya 2 atau sebesar $9 \%$ orang yang memiliki motivasi sedang.

Untuk penilaian hasil belajar yang dilakukan pada akhir pertemuan ke-2 diperoleh data hasil belajar sebagaimana tabel 5 sebagai berikut.

Tabel 5 : Hasil Belajar Siswa pada Siklus II

\begin{tabular}{rcccc}
\hline No. & Jumlah Siswa & Nilai & Persentase & Keterangan \\
\hline 1. & 21 orang & $\geq 70$ & $91 \%$ & Tuntas \\
\hline 2. & 2 orang & $<70$ & $9 \%$ & Tidak Tuntas \\
\hline
\end{tabular}

Berdasarkan tabel 5 di atas dapat diketahui bahwa dari 23 siswa sebanyak 21 orang (91\%) telah tuntas (mampu mencapai KKM 70), sedangkan sisanya sebanyak 2 orang (9\%) belum tuntas. Ketuntasan klasikal telah mencapai $91 \%$. Dengan demikian tindakan pada siklus II ini telah mampu memenuhi indikator keberhasilan tindakan yang ditetapkan karena siswa yang memiliki motivasi tinggi dan sangat tinggi adalah $91 \%>85 \%$, dan ketuntasan hasil belajar $91 \%>85 \%$.

\section{PEMBAHASAN}

Berdasarkan hasil pelaksanaan siklus I dan II, diketahui bahwa telah terjadi peningkatan motivasi belajar siswa dari siklus I ke siklus II. Peningkatan motivasi belajar siswa ini dapat dilihat pada tabel 6 berikut ini.

Tabel 6 : Perbandingan Motivasi Belajar Siswa Siklus I dan Siklus II 


\begin{tabular}{clcccc}
\hline \multirow{2}{*}{ No } & \multirow{2}{*}{$\begin{array}{c}\text { Kategori Motivasi } \\
\text { Belajar }\end{array}$} & \multicolumn{2}{c}{ Siklus I } & \multicolumn{2}{c}{ Siklus II } \\
\cline { 3 - 6 } & & Jumlah & $\%$ & Jumlah & $\%$ \\
\hline 1 & Sangat tinggi & 4 & $17 \%$ & 12 & $52 \%$ \\
\hline 2 & Tinggi & 14 & $61 \%$ & 9 & $39 \%$ \\
\hline 3 & Sedang & 3 & $13 \%$ & 2 & $9 \%$ \\
\hline 4 & Rendah & 2 & $9 \%$ & - & - \\
\hline 5 & Sangat rendah & - & - & - & - \\
\hline & Jumlah & 23 & $100 \%$ & 23 & $100 \%$ \\
\hline
\end{tabular}

Motivasi siswa meningkat setelah pembelajaran dilakukan dengan dengan menggunakan model talking stick. Hal ini terungkap dari hasil observasi dan catatan lapangan selama proses pembelajaran serta hasil angket yang diisi oleh siswa. Hal ini sesuai dengan tiga indikator adanya motivasi belajar yang disampaikan oleh Slameto (2003) yaitu (a) adanya perhatian, (b) adanya ketertarikan, dan (c) adanya kesenangan. Sebab siswa yang telah memiliki perhatian, ketertarikan dan adannya kesenangan telah membangkitkan motivasi siswa untuk belajar.

Selama proses pembelajaran berlangsung, terutama pada siklus II, siswa sangat antusias menjawab pertanyaan dari guru, tampak wajah siswa lebih bersemangat, semua ingin tongkat itu berhenti tepat ditangan mereka ketika musik yang mengiringi itu terhenti. Raut wajah dan keceriaan siswa ini menjadi penanda tingginya motivasi siswa terhadap materi yang diajarkan setelah menggunakan model pembelajaran talking stick, ditambah lagi guru memberikan reward berupa nilai dan hadiah kecil seperti permen, suasana kelas riuh karena banyak siswa yang menginginkan musik berhenti tepat ketika ada tongkat ditangan mereka dan untuk siswa yang belum mampu menjawab diberikan hukuman berjoget ditengah-tengah lingkaran, hal ini membawa kesan seru bagi siswa karena motivasi belajar dapat tumbuh apabila siswa secara emosional terlibat dalam proses pembelajaran. Motivasi inilah yang mendorong siswa untuk mengikuti kegiatan pembelajaran dengan baik.

Tuntutan Standar Nasional Pendidikan Bab IV pasal 19 ayat 1 yaitu "proses pembelajaran pada satuan pendidikan diselenggarakan secara interaktif, inspiratif, menyenangkan, menantang, memotivasi pembelajar untuk berpartisipasi aktif, dan memberikan ruang yang cukup bagi prakarsa, kreativitas, dan kemandirian sesuai dengan bakat, motivasi, dan perkembangan fisik serta psikologis peserta didik siswa" (UU Nomor 20 Tahun 2003). Dengan demikian penggunaan kegiatan talking stick telah mampu menjawab tuntutan Standar Nasional tersebut karena telah mampu meningkatkan motivasi siswa.

Peningkatan motivasi belajar yang telah dicapai di atas sangat berpengaruh pada hasil belajar siswa. Karena motivasi belajar yang tinggi akan membuat siswa secara psikis dan fisik lebih giat mengikuti pembelajaran sehingga memudahkannya memahami materi pembelajaran. Hal ini sesuai dengan penelitian Achyanadia (2013) yang menyatakan bahwa motivasi belajar memiliki pengaruh yang besar yaitu $69,4 \%$ terhadap hasil belajar siswa. Selain itu, peran guru dalam proses kegiatan pembelajaran talking stick mampu merangsang motivasi siswa jadi lebih bersemangat dalam belajar sehingga memperoleh hasil belajar yang lebih baik. Trik guru yang memberikan reward nilai dan permen pada siswa yang berhasil menjawab soal-soal yang diberikan dengan baik dan benar.

Kegiatan pembelajaran menggunakan model pembelajaran talking stick membuat siswa semakin antusias untuk menjawab soal-soal karena diringi dengan 
KARANGAN: Jurnal Kependidikan, Pembelajaran, dan Pengembangan, Vol 02, No 01, Bln Feb, Tahun 2020, Hal 7 - 14

lagu-lagu yang sedang hits dan kekinian sesuai dengan selera anak remaja masa kini, sementara untuk siswa yang belum mampu menjawab diberikan hukuman berjoget ditengah-tengah lingkaran, hal ini membawa kesan tersendiri bagi siswa. Siswa tidak lagi tegang dan sibuk melempar atau menghindari tongkat yang seharusnya mereka pegang guru berfungsi guru hanya sebagai pembimbing/ fasilitator, karena siswa lebih banyak beraktivitas. Kemampuan siswa dalam menjawab soal-soal menunjukkan bahwa siswa telah menguasai materi yang dipelajarinya. Demikian pula dengan hasil uji belajar yang dilakukan pada akhir siklus II berhasil meningkatkan nilai hasil belajar siswa. Peningkatan hasil belajar siswa dari siklus I ke siklus II dapat dilihat pada tabel 7 berikut ini.

Tabel 7 : Perbandingan Hasil Belajar Siswa pada Siklus I dan Siklus II

\begin{tabular}{clcc}
\hline No & \multicolumn{1}{c}{ Aspek } & Siklus I & Siklus II \\
\hline 1 & Jumlah siswa yang tuntas & 17 & 21 \\
\hline 2 & Jumlah siswa yang tidak tuntas & 6 & 2 \\
\hline 3 & Tingkat ketuntasan & $74 \%$ & $91 \%$ \\
\hline
\end{tabular}

Sesuai dengan indikator keberhasilan tindakan yang ditetapkan dalam penelitian ini yaitu (a) motivasi belajar 85\% siswa harus masuk kategori tinggi atau sangat tinggi, dan (b) ketuntasan klasikal $\geq 85 \%$ siswa yang memperoleh nilai minimal KKM sebesar 70, maka penelitian tindakan kelas ini dapat dinyatakan telah berhasil

\section{SIMPULAN DAN SARAN}

\section{Simpulan}

Berdasarkan hasil penelitian ditarik simpulan sebagai berikut: 1) penerapan model talking stick dapat meningkatkan motivasi belajar siswa dalam mata pelajaran IPA SMP, dan 2) penerapan model talking stick dapat meningkatkan hasil belajar siswa dalam mata pelajaran IPA SMP.

\section{Saran}

Untuk penelitian selanjutnya dapat menggunakan model pembelajaran talking stick yang dipadu dengan media pembelajaran yang inovatif agar pembelajaran lebih menarik.

\section{DAFTAR RUJUKAN}

Achyanadia, Septy. 2013. Hubungan Kebiasaan Belajar dan Motivasi Belajar dengan Hasil Belajar IPA Siswa Kelas VII SMP Negeri 1 Ciseeng. Jurnal Teknologi Pendidikan. Volume 2(2). 2013. Bogor: Universitas Ibnu Khaldun. www.googlecendekia.com. Jurnal diakses pada tanggal 1 April 2018.

Andayani, Suci. Sonja V.T. Lumowa. Didimus Tanah Boleng. 2016. Pengaruh Model Pembelajaran Kooperatif Tipe Think Pair Share dan Talking Stick terhadap Motivasi dan Hasil Belajar Kognitif IPA Biologi Siswa Kelas VII SMP. Jurnal Pendidikan: Teori, Penelitian \& Pengembangan. Vol. 1. No. 11. Nopember 2016. Malang: Universitas Negeri Malang. www.googlecendekia.com. Jurnal diakses pada tanggal 20 Februari 2018.

Aqib, Zainal. 2006. Penelitian Tindakan Kelas Untuk Guru. Bandung: Yrama Widya 
Hamzah, H.M. Ali dan Muhlisrarini. 2014. Perencanaan dan Strategi Pembelajaran Matematika. Cetakan Ke-1. Jakarta: PT. Raja Grafindo Persada.

Kemmis, S. dan MC. Taggart.R. Ed. 1988. The Action Resesarch Planner. Australia : Deakin University.

Kurniasih, Imas dan Berlin Sani. 2015. Ragam Pengembangan Model Pembelajaran: Untuk Peningkatan Profesionalitas Guru. Cetakan Ke-1. Jakarta: Kata Pena.

Putri, Ade Irma Kurnia Dwi. Trapsilo Prihandono. Pramudya Dwi Aristya Putra. 2017. Penerapan Model Pembelajaran Talking Stick Disertai Metode Demonstrasi Berbantuan Media Kokami Mata Pelajaran IPA di SMP. Jurnal Pembelajaran Fisika. Vol. 5 No. 4. Maret 2017. Hal 321-328. www.googlecendekia.com. Jurnal diakses pada tanggal 20 Februari 2018.

Slameto. 2003. Belajar dan Faktor-Faktor yang Mempengaruhinya. Jakarta: Rineka Cipta.

Suwatra, I Wayan, dkk. 2007. Modul Belajar dan Pembelajaran Singaraja: UNDIKSHA.

Undang-Undang Republik Indonesia Nomor 20 Tahun 2003 Tentang Sistem Pendidikan Nasional. Bandung: Citra Umbara 